\title{
An Update on Drug-induced Oral Reactions
}

\author{
Hila Yousefi ${ }^{1}$ and Mohammad Abdollahi ${ }^{1,2}$ \\ ${ }^{1}$ Toxicology and Diseases Group, The Institute of Pharmaceutical Sciences, Tehran University of Medical Sciences, \\ Tehran, Iran. ${ }^{2}$ Department of Toxicology and Pharmacology, Faculty of Pharmacy, Tehran University of Medical Sciences, \\ Tehran 1417614411, Iran.
}

Received April 12, 2018; Revised, May 15, 2018; Accepted May 15, 2018; Published, May 16, 2018.

\begin{abstract}
Adverse drug reactions (ADRs) are one of the major culprits in the development of oral lesions, which can be misdiagnosed with underlying diseases. The goal of this study is to summarize and update the current knowledge about drug-induced oral reactions. Electronic searches were performed in Scopus, Google Scholar, Cochrane and PubMed databases, for articles published between January 2008 and August 2017. Two authors screened the titles and abstracts for eligibility. Finally, 56 studies included in this review. There was no systematic homogeneity in the included studies; thereby no meta-analysis was performed. The most frequent oral ADR was xerostomia, and the most reported cause was antihypertensive medications. Cardiovascular drugs were the most reported culprit agents for induction of oral ulcerative and vesiculo-bullous lesions, followed by methotrexate. Nonsteroidal anti-inflammatory drugs (NSAIDs) and $\beta$-blockers were found the most common responsible drugs for induction of oral lichen planus.
\end{abstract}

This article is open to POST-PUBLICATION REVIEW. Registered readers (see "For Readers") may comment by clicking on ABSTRACT on the issue's contents page.

\section{INTRODUCTION}

Adverse drug reactions (ADRs) are one of the major culprits in the development of oral lesions, which can be mistaken for underlying diseases. Oral ADRs could manifest with a wide variety of clinical manifestations,including xerostomia / hyposalivation, ulcerative lesions, vesiculobullous lesions, red/white and pigmented lesions, and dental anomalies (1-5).

In 2000, the WHO definition of adverse drug reaction was modified as follows: "an appreciably harmful or unpleasant reaction, resulting from an intervention related to the use of a medicinal product, which predicts hazard from future administration and warrants prevention or specific treatment, or alteration of the dosage regimen, or withdrawal of the product." (6). Their definition leaves open the opportunity of using the terms "adverse reaction" and "adverse effects" interchangeably, in keeping with the understanding that adverse effect points to the drug standpoint, while adverse reaction points to the patient standpoint (7).

A wide spectrum of unusual oral manifestations can be attributable to drug consumption, some of which carry a high mortality rate such as toxic epidermal necrolysis (TEN) and Stevens-Johnson syndrome (SJS) (8). Therefore, as a key point in diagnosis of the oral anomalies, updating the knowledge regarding oral ADRs merits serious consideration. The goal of this review was to update the previous reviews by Abdollahi et al $(5,9)$ and reevaluate the literature since 2008 to update the data of the manifestations of adverse drug reactions in the oral cavity, aimed at strengthening our future diagnostic and therapeutic modalities.

We searched Scopus, Google Scholar, Cochrane and PubMed databases, for articles published between January 2008 and August 2017. The research method was developed following the policies and standards set forth by the Task Force for World Workshop on Oral Medicine VI (WWOM VI) (10) and the PRISMA (Preferred Reporting Items for Systematic Reviews and MetaAnalyses) statement (11). In addition, all references retrieved manually. The study selection process is described in Chart 1.

\footnotetext{
Corresponding Author: Mohammad Abdollahi, PharmD, $\mathrm{PhD}$, The Institute of Pharmaceutical Sciences and Faculty of Pharmacy, Tehran University of Medical Sciences, Pour Sina Str., Tehran, Iran, Email address: Mohammad@TUMS.Ac.Ir or Mohammad.Abdollahi@UToronto.Ca
} 
Chart 1. Adapted PRISMA (Preferred Reporting Items for Systematic Reviews and Meta-Analyses) flowchart of the paper selection process

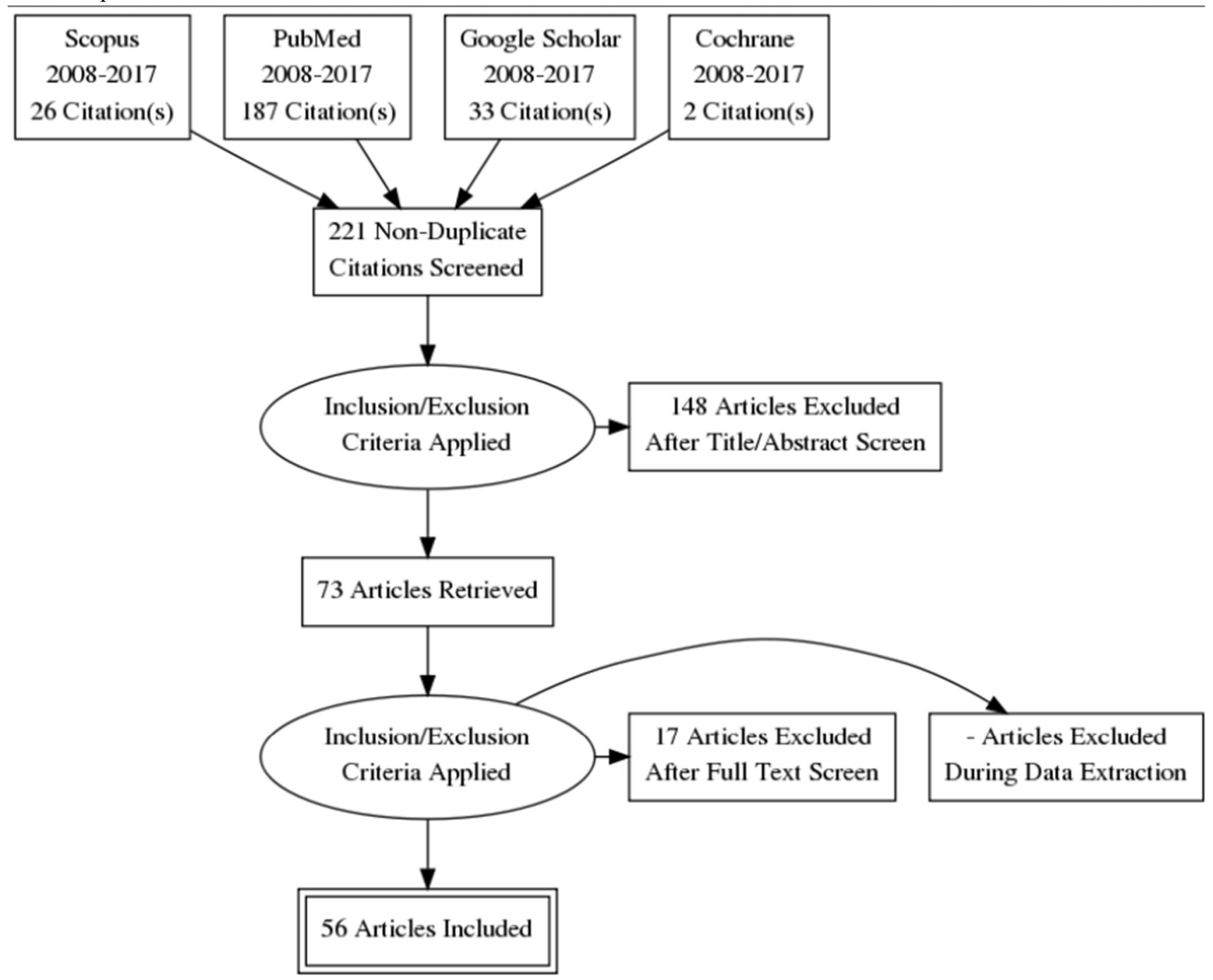

\section{Formulating the Review Question}

The patient population, intervention, comparison, and outcome framework formulated to the following question:

Does any ADR in oral cavity happen in patients undergoing drug consumption in comparison to non-drug users?

\section{Inclusion Criteria}

Any organized report of oral lesions induced by ADRs has been included in this review. Comparative, non-comparative, cross-sectional, prospective, and retrospective clinical studies published in English from January 2008 to August 2017 were included.

\section{Exclusion Criteria}

The articles that did not meet the mentioned inclusion criteria, animal studies, and in vitro studies.

\section{Review of literature}

Electronic searches were performed in the PubMed, Scopus, Google Scholar, and the Cochrane Library to identify studies meeting the inclusion criteria. The following search strategy was performed:

1. Drug reactions

2. Adverse drug effect

3. Drug-induced oral ulcers

4. Oral ulcerative lesions 
5. Oral white lesions

6. Oral red lesions

7. Oral Vesiculobullous lesions

8. Oral pigmented lesions

9. Benign oral lesions

10. Dental anomalies

11. Salivary gland dysfunction

12. \#1 OR \#2

13. \#3 OR \#4 OR \#5 OR \#6 OR \#7 OR \#8 OR \#9 OR \#10 OR \#11

14. \#12 AND \#13

In addition, in Google Scholar the following general key words were used to optimize the search strategy: oral adverse drug reactions, oral drug toxicity, and oral medicine toxicity.

\section{Study Selection}

The titles and abstracts of all articles identified in the electronic search, were screened by authors. Articles that met the exclusion criteria were excluded upon reviewers' agreement. Final included articles were undergone to a full text review.

\section{Data extraction}

The following data were extracted and tabulated in an Excel sheet by investigators as much as available in articles: publication year, country of publication, number of patients, sex, age, ADR, culprit medication and the dose, clinical features of lesions, duration of follow-up, and period of taking the culprit medication. Finally the sorting of lesions performed based on Burket's classification (12).

\section{STATISTICAL ANALYSIS}

There was no systematic homogeneity in the included studies; thereby no meta-analysis was performed.

\section{RESULTS and DISCUSSION}

248 studies were initially identified through an electronic search, and 27 studies were included via a manual hand search. From these, 192 studies were excluded based on exclusion criteria. The remaining 56 studies were subjected to full-text review (Chart $1)$.
Xerostomia was the most common oral ADR, and the most reported culprit drugs were antihypertensive medications followed by cardiovascular drugs as the second culprit agents for xerostomia. NSAIDs and $\beta$-blockers were the most common drugs responsible for oral lichen planus (LP). Cardiovascular drugs were the most reported culprit agents for induction of oral ulcerative and vesiculo-bullous lesions followed by methotrexate. One not widely known detrimental effect of bisphosphonates is mucosal ulcerations, which can lead to intense pain causing severe morbidity.

\section{Xerostomia and hyposalivation}

It has been well accepted that saliva plays a pivotal role in oral health and systemic health alike. Its unequaled mixture of water, ions, proteins and glycoproteins foster numbers of privileges, including immune privilege, wound repair, tooth remineralization, facilitation of swallowing and speech, initial digestion of starches and lipids $(13,14)$. Hence, a reduction in salivary flow sets the stage for hampering oral health and general individual well-being (15), and usually leads to xerostomia (i.e., the subjective feeling of dry mouth) (14).

Our results showed that the most common oral ADR is xerostomia. The list of drugs leading to xerostomia have been summarized in Table 1. A significant relationship has been reported between consumption of beta-blockers and xerostomia (16). Beta-blockers have been introduced as a key evidence-based treatment to reduce morbidity and mortality alongside angiotensin converting enzyme (ACE) inhibitors and aldosterone antagonists. The use of beta-blockers has been given a class I recommendation in patients suffering from symptomatic systolic heart failure (HF) by Current European and American guidelines (17).

In 2012, Nonzee et al, found the significant contribution between antihypertensive medications and xerostomia. In this case-control study, they compared 200 healthy controls with 200 hypertensive patients undergoing anti-hypertensive medication. Measuring un-stimulatory salivary flow rates at 1,2 and 3 minutes they found that the results were significantly lower in the hypertensive group at each time point. Besides the stimulatory salivary flow rate was significantly lower in case group alike. In this study, the mean stimulatory and 
un-stimulatory salivary flow rate had been reported as follows: $23.11 \pm 6.08$ for unstimulatory saliva rate, and $0.73 \pm 0.30$ for stimulatory saliva flow rate, also $50 \%$ prevalence of xerostomia and $57 \%$ prevalence of hyposalivation had been reported. They also indicated that the mean levels of mutans streptococci, Lactobacilli spp. and Candida spp. were significantly higher in the patient group. Their results illustrated that DMFT and missing teeth in the medicated group were significantly higher (18).

A significant relationship between xerostomia and taking anti-hypertensive drugs have been detected in a study by Djukic et al. They reported the data of 387 patients, $20 \%$ of which had diabetes mellitus (DM) type 2 as well. They illustrated that xerostomia was significantly more frequent in patients treated with metoprolol as monotherapy, combinations of enalapril with metoprolol, enalapril with hydrochlorothiazide, and enalapril with metoprolol and hydrochlorothiazide, regardless the presence of DM type 2, while there was no significant relationship between xerostomia and taking enalapril as monotherapy. The data of their study illustrated that xerostomia is more prevalent in hypertensive patients with DM type 2, except for DM type 2 patients treated with metoprolol as monotherapy. In this study, the researchers unraveled that enalapril is an independent factor which is well capable of moderately reducing the risk of development of xerostomia; while with sharp contrast metoprolol is an independent risk factor for development of xerostomia. More impressive, combinations of enalapril with metoprolol and/or hydrochlorothiazide are not independent risk factors (19).

\section{Oral Ulcerative and Vesiculo-bullous lesions}

Clinically, there are 2 types of drug-induced oral ulcers (20): The first is widespread mucositis and ulceration, the culprit of which is anti-tumor chemotherapy. Although several cancer therapeutic modalities are growing (21), anti-tumor chemotherapy with cytotoxic drugs is the most accepted modality. Such toxic anti-tumor agents have been summarized in Table 2. The risk factors and frequencies of altered oral health and odontogenesis in childhood cancer survivors have been described as follows: microdontia, hypodontia, root abnormalities, abnormal enamel, xerostomia, tooth loss $\geq 6$, and severe gingivitis (22). The summary of oral complications of cancer therapy has been shown in Box 2 .

The second type is fixed drug eruption, with the manifestation of recurrent treatment-resistant ulcers (20). Fixed drug eruption ulcerations can appear on every site of the oral mucosa. Typically, fixed drug eruption ulceration is larger than aphthous ulceration, with a flat surface and slightly white appearance. The ulcer has a definite margin and often slightly raised with no induration. Fixed drug eruption ulcers often resemble traumatic ulcers with no irritant factors in their vicinity (20). The list of drugs with potential to cause oral ulcerative and vesiculo-bullous lesions, has been summarized in Table 3.

The drug intake has been reported as the most common cause of outbreaks of Pemphigus vulgaris (PV) (23). The list of drugs have been summarized in Box 1.

Table 1. Drugs leading to xerostomia

\begin{tabular}{|c|c|c|c|c|c|}
\hline First author,year & Type of Study & Drug & $p$ & $\mathbf{n}$ & Ref. \\
\hline Wolff et al., 2008 & Case-control & $\begin{array}{c}50 \% \text { cardiovascular medication/ tranquilizers \& } \\
\text { sedatives }(43 \%) / \text { antidepressants }(14 \%) / \\
\text { antihistamines }(11 \%) / \text { gastrointestinal drugs }(10 \%)\end{array}$ & N.A & 246 & $(37)$ \\
\hline Almeida et al., 2008 & Case-control & Antidepressants(SSRIs) & N.A & 16 & $(38)$ \\
\hline Matos et al., 2010 & Case-control & Beta-blocker & $<0.05$ & 20 & (16) \\
\hline Nonzee et al.,2012 & Case-control & Antihypertensive medications & $<0.05$ & 200 & (18) \\
\hline Habbab et al., 2010 & Cross-sectional & Cardiovascular drugs & N.A & 40 & (24) \\
\hline Hasan et al., 2011 & Cross-sectional & $\begin{array}{l}\text { ARTs[3Top:lamivudine(64.6\%), } \\
\text { zidovudine(40.6\%), stavudine(23.7\%)] }\end{array}$ & N.A & 325 & (39) \\
\hline
\end{tabular}




\begin{tabular}{|c|c|c|c|c|}
\hline Djukic et al., 2015 & Cross-sectional & Antihypertensive medications & $<0.05$ & 387 \\
\hline Desoutter et al., 2012 & $\begin{array}{c}\text { Retrospective } \\
\text { epidemiological study }\end{array}$ & Anticholinergic medications & N.A & 287 \\
\hline
\end{tabular}

n: Number of cases; N.A: Not Available; SSRIs: Selective Serotonin Reuptake Inhibitors; ART: AIDS Related Therapy; Ref: reference

Box 1. The drugs involved in inducing or triggering pemphigus grouped according to their chemical structure

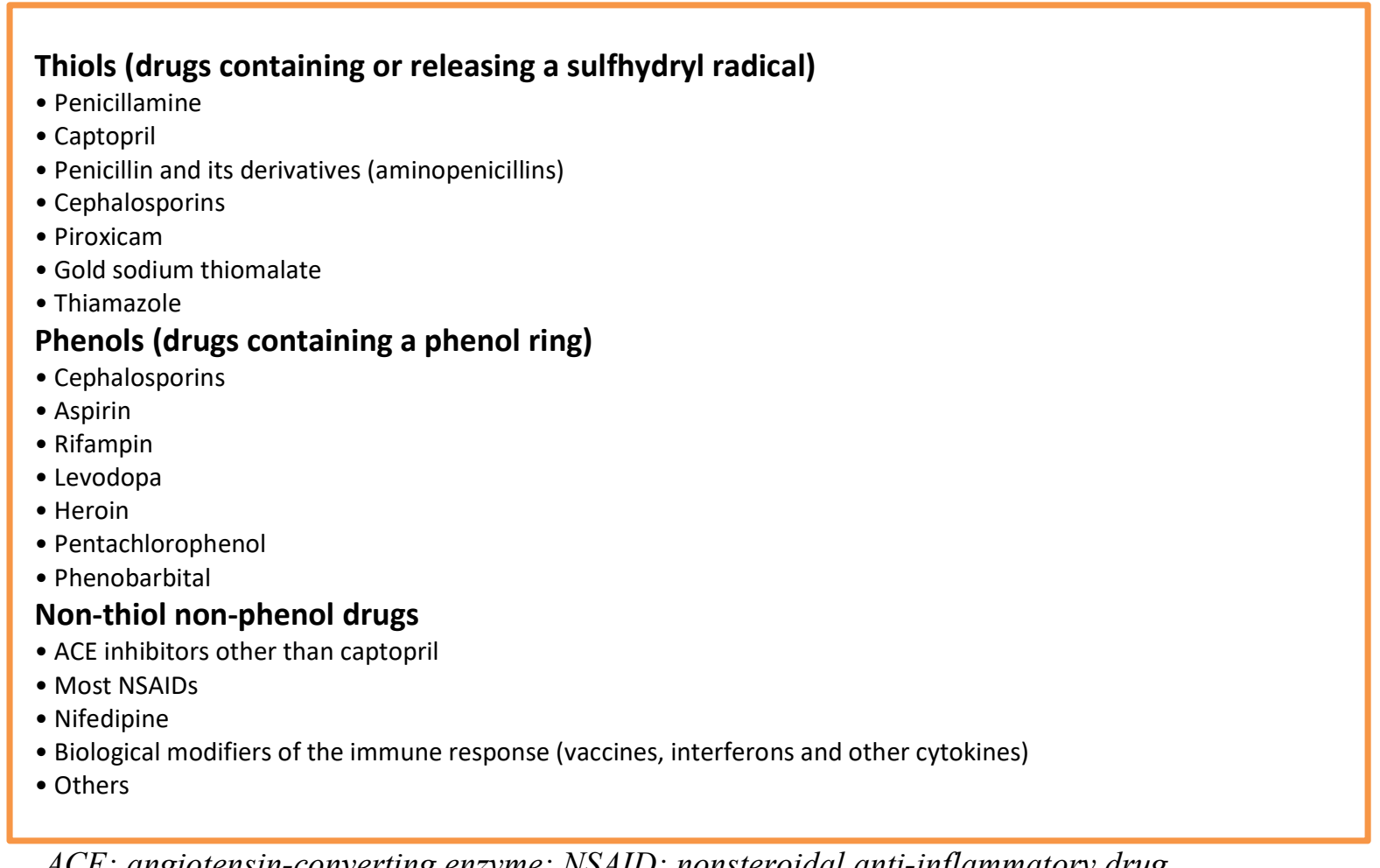

ACE: angiotensin-converting enzyme; NSAID: nonsteroidal anti-inflammatory drug

Habbab et al (24) investigated 531 patients from Saudi Arabia taking cardiovascular drugs (CVDs). Aphthous-like ulcerations were found in 5 patients $(0.9 \%)$ but the difference was not statistically significant. Recurrent aphthous stomatitis (RAS) is the most common oral painful ulcerative inflammatory disease of unknown etiology; thereby its management has been remained a challenge yet (25). Compelling evidences demonstrate that some immune dysfunctions may underlie RAS pathogenesis (26). This report is of importance for dentists aimed at strengthening therapeutic modalities.

Although the most common ADR for bisphosphonates is bisphosphonate-related osteonecrosis, it is notable that one not widely known detrimental effect of bisphosphonates is mucosal ulcerations, the summary of which has been reported in Table 4. It is of great importance for oral health care specialists and physicians to be alert to this possible complication of bisphosphonates. In 2008, 5 cancer patients treated with intravenous bisphosphonate were reported, who presented painful tongue ulcerations (27). Reviewing this not widely known adverse effect of alendronate has illustrated that misuse of alendronate such as keeping the pill in the mouth and not immediately swallowing it, is the most culprit of oral ulcers. It is notable that ulcers also appeared after correct administration (28). The appearance of the ulcers varied from a few days to several months after the start of alendronate use. Alendronate-induced oral ulcers can lead to severe pain causing severe morbidity (29). Careful monitoring of patients undergoing bisphosphonates medication is highly recommended. 


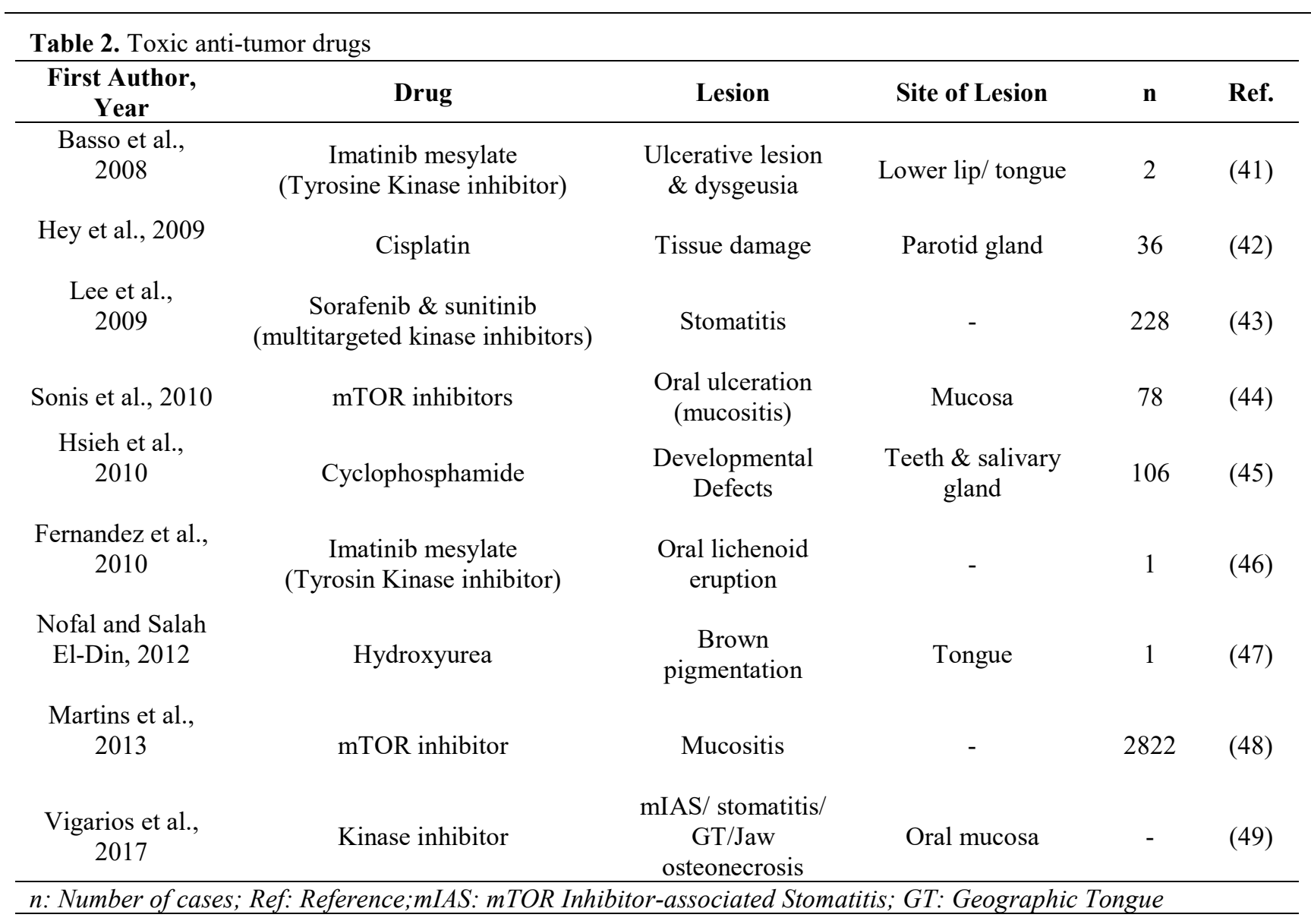

Table 3. Studies reported Oral Ulcerative and Vesiculo-bullous lesions, as oral ADRs

\begin{tabular}{|c|c|c|c|c|}
\hline First Author, Year & Drug & n & Sex & Ref. \\
\hline Jinbu et al., 2008 & Methotrexate & 1 & $\mathrm{M}$ & $(50)$ \\
\hline Gupta et al., 2009 & Gabapentin 300 & 1 & M & $(51)$ \\
\hline Habbab et al., 2010 & Cardiovascular drugs & 75 & - & $(24)$ \\
\hline Kikuchi et al., 2010 & Methotrexate & 1 & M & $(52)$ \\
\hline Pedrazas et al., 2010 & Methotrexate & 28 & $\mathrm{~F}: 25 / \mathrm{M}: 3$ & $(53)$ \\
\hline Mendonca et al., 2011 & Hydroxyurea & 2 & - & $(54)$ \\
\hline Weng et al., 2011 & Immunosuppressive drugs: (mycophenolate mofetil) & 1 & M & $(55)$ \\
\hline Lee et al., 2011 & Methotrexate & 1 & $\mathrm{~F}$ & $(56)$ \\
\hline Baričević et al., 2013 & ACE inhibitor(lisinopril) & 1 & $\mathrm{~F}$ & $(57)$ \\
\hline Troeltzsch et al., 2013 & Methotrexate & 2 & $\mathrm{~F}$ & $(58)$ \\
\hline Hanakawa et al., 2013 & Methotrexate & 1 & M & $(59)$ \\
\hline Jinbo, 2014 & Indomethacin/ nicorandil/ DPP-4 inhibitors(DM2) & 3 & $\mathrm{~F} / \mathrm{M} / \mathrm{F}$ & $(20)$ \\
\hline Dervisoglou, 2015 & Methotrexate & 3 & $\mathrm{~F} / \mathrm{F} / \mathrm{M}$ & $(60)$ \\
\hline Sahraei et al., 2016 & Misoprostol & 1 & $\mathrm{~F}$ & (61) \\
\hline \multicolumn{5}{|c|}{$\begin{array}{l}n: \text { Number of cases; Ref: Reference; TNF-a: Tumor Necrosis Factor-a; DPP-4: Dipeptidyl Peptidase 4; DM: Diabetes } \\
\text { Mellitus; ACE: Angiotensin-Converting Enzyme; F: Female; M: Male }\end{array}$} \\
\hline
\end{tabular}

\section{Red/White Lesions and Mucosal Pigmented Lesions}

The drugs leading to red/white lesions and mucosal pigmented lesions have been shown in Table 5 .
The most prevalent drug-induced red/white lesion is oral lichenoid drug eruption. Diagnosing of druginduced LP can be challenging, and the main clue is the time course of mucosal involvement in relation 
to the drug and confirmed by rechallenge (30). The result of a retrospective review has illustrated that beta-blockers and nonsteroidal anti-inflammatory drugs (NSAIDs) are associated with oral LP. A significant protective effect of ACE inhibitors from developing mucosal LP $(p<0.01)$ has been found and it has been suggested that such a protective effect could be the result of a direct inhibitory effect of the drug on activated T cells (31). In 2011, Hirota et al, performed a control study aimed at investigating a possible association between oral LP and drug intake. They compared 110 OLP patients with healthy controls, and found that lichenoid drug reactions are likely to occur only in a very low percentage of patients (31). The association of use of medications with geographic tongue (GT) and fissured tongue (FT) lesions has been investigated, and the association between GT and antihypertensive medications has been detected (32). The result of a case-control study showed that hydroxychloroquine (HCQ)-induced pigmentation is not a rare adverse effect of HCQ, also it has been found that HCQ-induced pigmentation- with a high probability- is secondary to ecchymosis or bruising (33) .

Box 2. Summarized oral complications of cancer therapy.

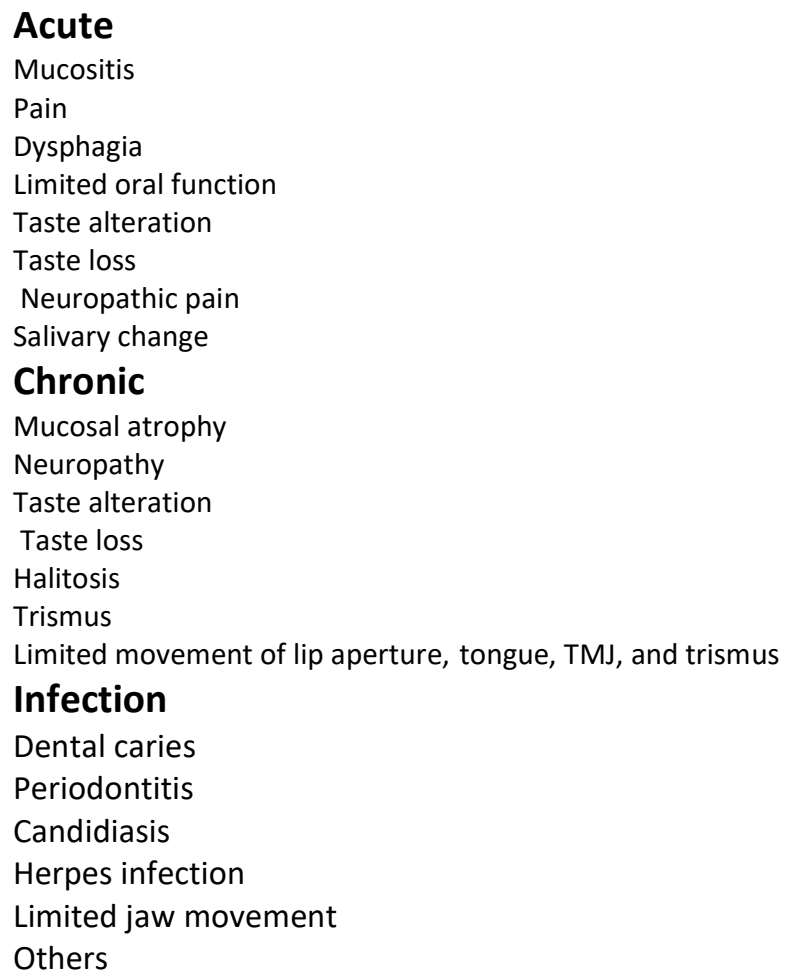

Summarized and updated from the paper of Epstein et al. (77) by permission (license code: 4354031380697).

Table 4. Bisphosphonates reported as culprit for oral ulceration

\begin{tabular}{|c|c|c|c|c|c|}
\hline $\begin{array}{c}\text { First Author, } \\
\text { Year }\end{array}$ & Drug & Reported location & Characteristics & $\mathbf{n}$ & Ref. \\
\hline Aleid, 2009 & Alendronate (Tablet) & Tongue (Both sides) & Erosive ulcer & 1 & $(62)$ \\
\hline $\begin{array}{c}\text { Kharazmi et al., } \\
2010\end{array}$ & Alendronate (Tablet) & Tongue (entire dorsum) & $\begin{array}{l}\text { Thick ulcer \& well- } \\
\text { defined borders }\end{array}$ & 1 & (29) \\
\hline $\begin{array}{c}\text { Kharazmi et al., } \\
2012\end{array}$ & Alendronate (Tablet) & Palate \& Tongue & $\begin{array}{l}\text { Mostly Thick bullae with } \\
\text { distinct borders }\end{array}$ & 13 & $(28)$ \\
\hline
\end{tabular}




\begin{tabular}{|c|c|c|c|c|c|}
\hline First Author, Year & Drug & Lesion & $\mathbf{n}$ & Sex & Ref. \\
\hline \multirow{2}{*}{$\begin{array}{c}\text { Puri et al., } 2008 \\
\text { Clayton et al., } 2009\end{array}$} & Hydroxychloroquine & Hyperpigmentation & 2 & $\mathrm{~F}$ & (63) \\
\hline & NSAIDs/ $\beta$-blockers & Oral LP & 106 & $\mathrm{~F}$ & $(30)$ \\
\hline \multirow{2}{*}{$\begin{array}{c}\text { Woo et al., } 2009 \\
\text { Asarch, } 2009\end{array}$} & $\begin{array}{c}\text { Risperidone/Carbamazepine } \\
\text { (Tegretol) }\end{array}$ & $\begin{array}{l}\text { Lichenoid Drug } \\
\text { Eruption }\end{array}$ & 1 & M & $(64)$ \\
\hline & TNF-a inhibitors & Lichenoid reaction & 2 & $\mathrm{~F} / \mathrm{M}$ & $(65)$ \\
\hline \multirow{2}{*}{$\begin{array}{c}\text { Habbab et al., } 2010 \\
\text { Kaomongkolgit, } 2010\end{array}$} & Cardiovascular drugs & Lichenoid lesion & 19 & - & (24) \\
\hline & $\begin{array}{l}\text { Antihypertensive \& } \\
\text { Hypoglycemic drugs }\end{array}$ & Lichenoid reaction & 1 & $\mathrm{M}$ & (66) \\
\hline Artico et al., 2011 & Carbamazepine & Lichenoid reaction & 1 & $\mathrm{M}$ & (67) \\
\hline Shino et al., 2011 & Valsartan (ARB) & $\begin{array}{l}\text { Angioedema } \\
\text { Mucosal }\end{array}$ & 1 & $\mathrm{M}$ & $(68)$ \\
\hline Li et al., 2012 & Imatinib & Pigmentation & 3 & M & $(69)$ \\
\hline Fessa et al., 2012 & $\beta$-Blockers & $\begin{array}{l}\text { Lichenoid Drug } \\
\text { Eruption }\end{array}$ & 1 & M & $(70)$ \\
\hline Balaji et al., 2014 & Linezolid (tablet) & Black hairy tongue & 1 & $\mathrm{M}$ & (71) \\
\hline Jallouli et al., 2014 & Hydroxychloroquine & Pigmentation & 24 & $\mathrm{~F}: 23 / \mathrm{M}: 1$ & (33) \\
\hline Dafar et al., 2015 & Antihypertensive medications & Geographic tongue & 130 & $\mathrm{M}: 78 / \mathrm{F}: 52$ & (32) \\
\hline Dafar et al., 2015 & Topical corticosteroids & Fissured tongue & 62 & $\mathrm{~F}: 32 / \mathrm{M}: 30$ & $(32)$ \\
\hline
\end{tabular}

\section{Benign oral lesions, Taste alteration and Dental Anomalies}

Drug classes associated with taste and smell alterations have been identified. A statistically significant odds ratio (OR) for fluoroquinolones, terbinafine, macrolides and protein kinase inhibitors have been reported (33). Gaultier et al, in 2009 examined 16 patients with a history of drug-induced toxic epidermal necrolysis (TEN) and StevensJohnson syndrome (SJS). All patients suffered from mouth discomfort, 13 had gingival inflammation, 14 had gingival recession, 9 were complained of altered tongue mucosa, and 6 had gingival synechiae. All patients had sicca syndrome, with reduced saliva volume and more acidic $\mathrm{pH}(\mathrm{pH}$ : $6.53)$ and lower buffering capacity $(8.9 \mathrm{mmol} / \mathrm{L})$, subsequently tooth caries were frequent among patients. Five out of 16 patients had severe dental growth abnormalities. Severe periodontitis was observed in 3 patients, 2 of them tested positive for both Porphyromonas gingivalis and Tannerella forsythia. These two bacteria were found in 5 and 9 patientsrespectively, while periodontal diseases were reported in 3 of cases (8).

The list of drugs with potential to induce benign oral lesions, taste alterations and dental anomalies have been summarized in Table 6 .

Table 6. Drugs leading to benign oral lesions and taste disorders and dental anomalies

\begin{tabular}{|c|c|c|c|c|}
\hline First Author, Year & Drug & Lesion & $\mathbf{n}$ & Ref. \\
\hline $\begin{array}{l}\text { Kumaraguru et al., } \\
2009\end{array}$ & Glibenclamide (glyburide) & $\begin{array}{l}\text { Tooth discoloration \& } \\
\text { enamel loss }\end{array}$ & 67 & $(72)$ \\
\hline Habbab et al., 2010 & Cardiovascular drugs & Dysgeusia/ G.E & 75 & (24) \\
\hline $\begin{array}{l}\text { Kharazmi et al., } \\
2010\end{array}$ & Alendronate (Tablet) & Taste loss & 1 & $(29)$ \\
\hline Matos et al.,2010 & Beta-blockers/ benzodiazepine anxiolytic & Higher DMFT $(p<0.05)$ & 2014 & $(16)$ \\
\hline
\end{tabular}




\begin{tabular}{|c|c|c|c|c|}
\hline Weng et al., 2011 & $\begin{array}{l}\text { Immunosuppressive drugs: (mycophenolate } \\
\text { mofetil) }\end{array}$ & G.E & 1 & $(55)$ \\
\hline Tuccori et al., 2011 & $\begin{array}{l}\text { Fluoroquinolones/terbinafine/ macrolides/ } \\
\text { protein kinase inhibitors }\end{array}$ & Taste \& Smell Alterations & 182 & (34) \\
\hline Nonzee et al., 2012 & antihypertensive medications & Higher DMFT $(p<0.05)$ & 200 & (17) \\
\hline $\begin{array}{l}\text { Troeltzsch et al., } \\
2013\end{array}$ & Methotrexate & NUG & 2 & $(58)$ \\
\hline $\begin{array}{l}\text { Petropoulou et al., } \\
2013\end{array}$ & Linezolid (IV) & $\begin{array}{l}\text { Teeth \& Tongue } \\
\text { Discoloration }\end{array}$ & 3 & (73) \\
\hline $\begin{array}{l}\text { Helenius-Hietala et } \\
\text { al., } 2014\end{array}$ & $\begin{array}{l}\text { Immunosuppression therapy(cyclosporine } \\
\text { A) }\end{array}$ & G.E & 84 & (74) \\
\hline $\begin{array}{l}\text { Hellwig \& Lussi., } \\
2014\end{array}$ & $\begin{array}{l}\text { Acidic or EDTA-containing oral hygiene } \\
\text { products and medicines }\end{array}$ & Dental Erosion & - & (75) \\
\hline Hu et al., 2016 & Antipsychotic medications & Dental caries & 2149 & (76) \\
\hline
\end{tabular}

\section{CONCLUSION}

This review showed that the most frequent oral ADR is xerostomia, and the most reported culprit drugs with significant results are antihypertensive medications $(18,19)$.

Cardiovascular drugs were the most reported culprit agents for induction of oral ulcerative and vesiculo-bullous lesions followed by methotrexate [Table 3]. NSAIDs, which are responsible for approximately $5-10 \%$ of all medications prescribed each year (35), and $\beta$-blockers are the most common drugs responsible for oral LP (26). Antihypertensive medications are major culprits for GT [Table 5]. It is estimated that more than one billion adults are hypertensive worldwide, which is projected to increase to 1.56 billion by the year 2025 (36). These findings support the notion that dentists should be aware of possible oral ADRs. Indeed, dissecting the patients' medical history help dentists for strengthening their therapeutic modalities.

\section{ACKNOWLEDGMENT}

This paper is the outcome of an in-house financially non-supported study. Authors declare no conflict of interest. Authors thank assistance of INSF.

\section{CONFLICT OF INTEREST}

The authors declare they have no conflict of interest.

\section{REFERENCES}

1. Zelickson BD, Rogers RS. Drug reactions involving the mouth. Clin Dermatol, 1986. 4(1):98-109.

2. Boras VV, Andabak-Rogulj A, Brailo V, Simunkovic SK, Gabric D, Vrdoljak DV. Adverse Drug Reactions in The Oral Cavity. Acta Clin Croat, 2015. 54(2): 208-15.

3. Yuan A, Woo SB. Adverse drug events in the oral cavity. Oral Surg Oral Med Oral Pathol Oral Radiol, 2015. 119(1): 35-47. Oral Surg Oral Med Oral Pathol Oral Radiol, 2015. 119(1): 35-47. doi: 10.1016/j.0ooo.2014.09.009.

4. Femiano F, Lanza A, Buonaiuto C, Gombos F, Rullo $\mathrm{R}$, Festa $\mathrm{V}$, et al. Oral manifestations of adverse drug reactions: guidelines. J Eur Acad Dermatol Venereol, 2008. 22(6): 681-91. doi: 10.1111/j.14683083.2008.02637.x.

5. Abdollahi M, Rahimi R, Radfar M. Current opinion on drug-induced oral reactions: a comprehensive review. J Contemp Dent Pract, 2008. 9(3): 1-15.

6. Edwards IR, Aronson JK. Adverse drug reactions: definitions, diagnosis, and management. Lancet, 2000. 356(9237): 1255-9. doi:10.1016/S01406736(00)02799-9.

7. Fortuna G, Aria M, Schiavo JH. Drug-induced oral lichenoid reactions: a real clinical entity? A systematic review. Eur J Clin Pharmacol, 2017. 73(12):1523-37. doi: 10.1007/s00228-017-2325-0.

8. Gaultier F, Rochefort J, Landru MM, Allanore L, Naveau A, Roujeau JC, et al. Severe and Unrecognized Dental Abnormalities After DrugInduced Epidermal Necrolysis. Arch Dermatol, $2009 . \quad 145(11): 1332-3 . \quad$ doi: 10.1001/archdermatol.2009.233. 
9. Abdollahi M, Radfar M. A review of drug-induced oral reactions. J Contemp Dent Pract, 2003. 4(1):1031.

10. Baccaglini L, Brennan MT, Lockhart PB, Patton LL. World Workshop on Oral Medicine IV: Process and methodology for systematic review and developing management recommendations. Reference manual for management recommendations writing committees. Oral Surg Oral Med Oral Pathol Oral Radiol Endod, 2007. 103 Suppl: S3.e1-19. doi: 10.1016/j.tripleo.2006.12.002

11. Moher D, Liberati A, Tetzlaff J, Altman DG. Preferred reporting items for systematic reviews and meta-analyses: the PRISMA statement. Int J Surg, 2010. 8(5): 336-41. doi: 10.1016/j.ijsu.2010.02.007.

12. Glick M. Burket's Oral Medicine. $12^{\text {th }}$ ed., People Medical Publishing House-USA, Chapter 4, 2016.

13. Pedersen AM, Bardow A, Jensen SB, Nauntofte B. Saliva and gastrointestinal functions of taste, mastication, swallowing and digestion. Oral Dis, 2002. 8(3): 117-29.

14. Aliko A, Wolff A, Dawes C, Aframian D, Proctor G, Ekstrom J, et al. World Workshop on Oral Medicine VI: clinical implications of medication-induced salivary gland dysfunction. Oral Surg Oral Med Oral Pathol Oral Radiol, 2015. 120(2): 185-206. doi: 10.1016/j.0ooo.2014.10.027.

15. Field EA, Longman LP, Bucknall R, Kaye SB, Higham SM, Edgar WM. The establishment of a xerostomia clinic: a prospective study. Br J Oral Maxillofac Surg, 1997. 35(2): 96-103.

16. de Matos LF, Pereira SM, Kaminagakura E, Marques LS, Pereira CV, van der Bilt A, et al. Relationships of beta-blockers and anxiolytics intake and salivary secretion, masticatory performance and taste perception. Arch Oral Biol, 2010. 55(2):164-9. doi: 10.1016/j.archoralbio.2009.11.011.

17. Kotecha D, Manzano L, Altman DG, Krum H, Erdem G, Williams N,et al. Individual patient data meta-analysis of beta-blockers in heart failure: rationale and design. Syst Rev, 2013. 18(1):2-7. doi: 10.1186/2046-4053-2-7.

18. Nonzee V, Manopatanakul S, Khovidhunkit SO. Xerostomia, hyposalivation and oral microbiota in patients using antihypertensive medications. J Med Assoc Thai, 2012. 95(1): 96-104.

19. Djukic LJ, Roganovic J, Brajovic MD, Bokonjic D, Stojic D. The effects of anti-hypertensives and type 2 diabetes on salivary flow and total antioxidant capacity. Oral Dis, 2015. 21(5): 619-25. doi: 10.1111/odi.12325.

20. Jinbo Y, Demitso T. Oral ulcerations due to drug medications. Jap Dent Sci Revi, 2014. 50(2): 40-6. https://doi.org/10.1016/j.jdsr.2013.12.001
21. Yousefi H, Yuan J, Keshavarz-Fathi M, Murphy JF, Rezaei N. Immunotherapy of cancers comes of age. Expert Rev Clin Immunol, 2017. 13(10):1001-15. doi: 10.1080/1744666X.2017.1366315.

22. Kaste SC, Goodman P, Leisenring W, Stovall M, Hayashi RJ, Yeazel M, et al. Impact of radiation and chemotherapy on risk of dental abnormalities: a report from the Childhood Cancer Survivor Study. Cancer, 2009. 115(24):5817-27. doi: 10.1002/cncr.24670.

23. Ruocco V, Ruocco E, Lo Schiavo A, Brunetti G, Guerrera LP, Wolf R. Pemphigus: etiology, pathogenesis, and inducing or triggering factors: facts and controversies. Clin Dermatol, 2013. 31(4): 374-81. doi: 10.1016/j.clindermatol.2013.01.004.

24. Habbab KM, Moles DR, Porter SR. Potential oral manifestations of cardiovascular drugs. Oral Dis, 2010. 16(8): 769-73. doi: 10.1111/j.16010825.2010.01686.x.

25. Firouze Moqadam I, Najafi S, Mohammadzadeh M, Zare Bidoki A, Yousefi H, Farhadi E, et al. Lack of Association between Interleukin-12 Gene Polymorphisms and Recurrent Aphthous Stomatitis. Avicenna J Med Biotechnol, 2016. 8(4): 200-201.

26. Najafi S, Yousefi H, Mohammadzadeh M, Bidoki AZ, Farhadi E, Rezaei N. Interleukin-2, Interferongamma Gene Polymorphisms in Recurrent Aphthous Stomatitis. Prague Med Rep, 2017. 118(2-3): 81-6. doi: 10.14712/23362936.2017.7.

27. Treister NS, Richardson P, Schlossman R, Miller K, Woo SB. Painful tongue ulcerations in patients with bisphosphonate-associated osteonecrosis of the jaws. Oral Surg Oral Med Oral Pathol Oral Radiol Endod, $2008.105(6): \quad 1-4 . \quad$ doi: 10.1016/j.tripleo.2008.02.010.

28. Kharazmi M, Sjoqvist K, Warfvinge G. Oral ulcers, a little known adverse effect of alendronate: review of the literature. J Oral Maxillofac Surg, 2012. 70(4): 830-6. doi: 10.1016/j.joms.2011.03.046.

29. Kharazmi M, Sjoqvist K, Rizk M, Warfvinge G. Oral ulcer associated with alendronate: a case report. Oral Surg Oral Med Oral Pathol Oral Radiol Endod, $2010 . \quad 110(6)$ : 11-3. doi: 10.1016/j.tripleo.2010.04.035.

30. Clayton R, Chaudhry S, Ali I, Cooper S, Hodgson T, Wojnarowska F. Mucosal (oral and vulval) lichen planus in women: are angiotensin-converting enzyme inhibitors protective, and beta-blockers and non-steroidal anti-inflammatory drugs associated with the condition? Clin Exp Dermatol, 2010. 35(4): 384-7. doi: 10.1111/j.1365-2230.2009.03581.x.

31. Hirota SK, Moreno RA, dos Santos CH, Seo J, Migliari DA. Analysis of a possible association between oral lichen planus and drug intake. A controlled study. Med Oral Patol Oral Cir Bucal, 2011. 16(6): 750-6. 
32. Dafar A, Cevik-Aras H, Robledo-Sierra J, Mattsson U, Jontell M. Factors associated with geographic tongue and fissured tongue. Acta Odontol Scand, $2016 . \quad 74(3)$ : 210-6. doi: 10.3109/00016357.2015.1087046.

33. Jallouli M, Frances C, Piette JC, Huong du LT, Moguelet P, Factor C, et al. Hydroxychloroquineinduced pigmentation in patients with systemic lupus erythematosus: a case-control study. JAMA Dermatol, 2013. 149(8): 935-40. doi: 10.1001/jamadermatol.2013.709.

34. Tuccori M, Lapi F, Testi A, Ruggiero E, Moretti U, Vannacci A, et al. Drug-induced taste and smell alterations: a case/non-case evaluation of an italian database of spontaneous adverse drug reaction reporting. Drug Saf, 2011. 34(10): 849-59. doi: 10.2165/11593120-000000000-00000.

35. Onder G, Pellicciotti F, Gambassi G, Bernabei R. NSAID-related psychiatric adverse events: who is at risk? Drugs,2004. 64: 2619-27.

36. Jarari N, Rao N, Peela JR, Ellafi KA, Shakila S, Said AR, et al. A review on prescribing patterns of antihypertensive drugs. Clin Hypertens, 2016. 27:22-7. doi: 10.1186/s40885-016-0042-0.

37. Wolff A, Zuk-Paz L, Kaplan I. Major salivary gland output differs between users and non-users of specific medication categories. Gerodontology, 2008. 25(4): 210-6. doi: 10.1111/j.17412358.2008.00223.x.

38. de Almeida Pdel V, Gregio AM, Brancher JA, Ignacio SA, Machado MA, de Lima AA, et al. Effects of antidepressants and benzodiazepines on stimulated salivary flow rate and biochemistry composition of the saliva. Oral Surg Oral Med Oral Pathol Oral Radiol Endod, 2008. 106(1): 58-65. doi: 10.1016/j.tripleo.2007.11.008.

39. Hasan SS, Keong SC, Choong CL, Ahmed SI, Ching TW, Anwar M, et al. Patient-reported adverse drug reactions and drug-drug interactions: a crosssectional study on Malaysian HIV/AIDS patients. Med Princ Pract, 2011. 20(3): 265-70. doi: $10.1159 / 000321274$.

40. Desoutter A, Soudain-Pineau M, Munsch F, Mauprivez C, Dufour T, Coeuriot JL. Xerostomia and medication: a cross-sectional study in long-term geriatric wards. J Nutr Health Aging, 2012. 16(6): 575-9.

41. Basso FG, Boer CC, Correa ME, Torrezan M, Cintra ML, de Magalhaes MH, et al. Skin and oral lesions associated to imatinib mesylate therapy. Support Care Cancer, 2009. 17(4): 465-8. doi: 10.1007/s00520-008-0536-8.

42. Hey J, Setz J, Gerlach R, Vordermark D, Gernhardt CR, Kuhnt T. Effect of Cisplatin on parotid gland function in concomitant radiochemotherapy. Int $\mathrm{J}$
Radiat Oncol Biol Phys, 2009. 75(5): 1475-80. doi: 10.1016/j.ijrobp.2008.12.071.

43. Lee WJ, Lee JL, Chang SE, Lee MW, Kang YK, Choi JH, et al. Cutaneous adverse effects in patients treated with the multitargeted kinase inhibitors sorafenib and sunitinib. $\mathrm{Br} \mathrm{J}$ Dermatol, 2009. 161(5): $\quad 1045-51 . \quad$ doi: $\quad 10.1111 /$ j.13652133.2009.09290.x.

44. Sonis S, Treister N, Chawla S, Demetri G, Haluska F. Preliminary characterization of oral lesions associated with inhibitors of mammalian target of rapamycin in cancer patients. Cancer, 2010. 116(1): 210-5. doi: 10.1002/cncr.24696.

45. Hsieh SG, Hibbert S, Shaw P, Ahern V, Arora M. Association of cyclophosphamide use with dental developmental defects and salivary gland dysfunction in recipients of childhood antineoplastic therapy. Cancer, 2011. 117(10): 2219-27. doi: 10.1002/cncr.25704.

46. Gomez Fernandez C, Sendagorta Cudos E, Casado Verrier B, Feito Rodriguez M, Suarez Aguado J, Vidaurrazaga Diaz de Arcaya C. Oral lichenoid eruption associated with imatinib treatment. Eur $\mathbf{J}$ Dermatol, 2010. 20(1): 127-8. doi: 10.1684/ejd.2010.0818.

47. Nofal A, El-Din ES. Hydroxyurea-induced dermatomyositis: true amyopathic dermatomyositis or dermatomyositis-like eruption? Int J Dermatol, 2012. 51(5): 535-41. doi: 10.1111/j.13654632.2011.05105.x.

48. Martins F, de Oliveira MA, Wang Q, Sonis S, Gallottini M, George S, et al. A review of oral toxicity associated with mTOR inhibitor therapy in cancer patients. Oral Oncol, 2013. 49(4): 293-8. doi: 10.1016/j.oraloncology.2012.11.008.

49. Vigarios E, Epstein JB, Sibaud V. Oral mucosal changes induced by anticancer targeted therapies and immune checkpoint inhibitors. Support Care Cancer, 2017. 25(5): 1713-39. doi: 10.1007/s00520017-3629-4.

50. Jinbu Y, Obi Y, Kawa R, Ikeda K, Kusama M, Tsukinoki K. Oral ulcerations due to an antirheumatic drug (Methotrexate) : report of a case. Oral Med Pathol, 2008. 12:97-9

51. Gupta S, Gupta S, Mittal A, David S. Oral fixed drug eruption caused by gabapentin. J Eur Acad Dermatol Venereol, 2009. 23(10): 1207-8. doi: 10.1111/j.1468-3083.2009.03124.x.

52. Kikuchi K, Miyazaki Y, Tanaka A, Shigematu H, Kojima M, Sakashita H, et al. Methotrexate-related Epstein-Barr Virus (EBV)-associated lymphoproliferative disorder--so-called "Hodgkinlike lesion"--of the oral cavity in a patient with rheumatoid arthritis. Head Neck Pathol, 2010. 4(4): 305-11. doi: 10.1007/s12105-010-0202-6. 
53. Pedrazas CH, Azevedo MN, Torres SR. Oral events related to low-dose methotrexate in rheumatoid arthritis patients. Braz Oral Res, 2010. 24(3): 36873.

54. Mendonca R, Gueiros LA, Capellaro K, Pinheiro VR, Lopes MA. Oral lesions associated with hydroxyurea treatment. Indian J Dent Res, 2011. 22(6): 869-70. doi: 10.4103/0970-9290.94690.

55. Weng RR, Foster CE,Hsieh LL, Patel PR. Oral ulcers associated with mycophenolate mofetil use in a renal transplant recipient. Am J Health Syst Pharm, 2011. 68(7): 585-8. doi: 10.2146/ajhp100276.

56. Lee HJ, Hong SK, Seo JK, Lee D, Sung HS. A Case of Cutaneous Side Effect of Methotrexate Mimicking Behcet's Disease. Ann Dermatol, 2011. 23(3): 412-4. doi: 10.5021/ad.2011.23.3.412.

57. Baricevic M, Mravak Stipetic M, Situm M, Marinovic B, Seiwerth S, Baricevic D, et al. Oral bullous eruption after taking lisinopril--case report and literature review. Wien Klin Wochenschr, 2013. 125(13-14): 408-11. doi: 10.1007/s00508-013-03827.

58. Troeltzsch M, von Blohn G, Kriegelstein S, Woodlock T, Gassling V, Berndt R, et al. Oral mucositis in patients receiving low-dose methotrexate therapy for rheumatoid arthritis: report of 2 cases and literature review. Oral Surg Oral Med Oral Pathol Oral Radiol, 2013. 115(5): 28-33. doi: 10.1016/j.0ooo.2012.12.008.

59. Hanakawa H, Orita Y, Sato Y, Uno K, Nishizaki K, Yoshino T. Large ulceration of the oropharynx induced by methotrexate-associated lymphoproliferative disorders. Acta Med Okayama, 2013. 67(4): 265-9.doi: 10.18926/AMO/51072

60. Dervisoglou T MA. Oral Ulceration Due to Methotrexate Treatment: A Report of 3 Cases and Literature Review. Balk J dent Med, 2015. 19(1): 116-120.doi: https://doi.org/10.1515/bjdm-20150045

61. Sahraei Z, Mirabzadeh M, Eshraghi A. Erythema Multiforme Associated With Misoprostol: A Case Report. Am J Ther, 2016. 23(5): 1230-3. doi: 10.1097/MJT.0000000000000193.

62. Aleid W, Sidebottom A. Oral mucosal irritation with incorrect use of alendronate. $\mathrm{Br} \mathrm{J}$ Oral Maxillofac Surg, 2009. 47(2): 170-1. doi: 10.1016/j.bjoms.2008.08.005.

63. Puri PK, Lountzis NI, Tyler W, Ferringer T. Hydroxychloroquine-induced hyperpigmentation: the staining pattern. J Cutan Pathol, 2008. 35(12): 1134-7. doi: 10.1111/j.1600-0560.2008.01004.x.

64. Woo V, Bonks J, Borukhova L, Zegarelli D. Oral lichenoid drug eruption: a report of a pediatric case and review of the literature. Pediatr Dermatol, 2009.

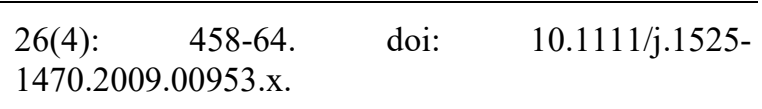

65. Asarch A, Gottlieb AB, Lee J, Masterpol KS, Scheinman PL, Stadecker MJ, et al. Lichen planuslike eruptions: an emerging side effect of tumor necrosis factor-alpha antagonists. J Am Acad Dermatol, 2009. 61(1): 104-11. doi: 10.1016/j.jaad.2008.09.032.

66. Kaomongkolgit R. Oral lichenoid drug reaction associated with antihypertensive and hypoglycemic drugs. J Drugs Dermatol, 2010. 9(1): 73-5.

67. Artico G, Bruno IS, Seo J, Hirota SK, Acay R, Migliari DA. Lichenoid reaction to carbamazepine in the oral mucosa: case report. An Bras Dermatol, 2011. 86(4 Suppl 1): S152-5.

68. Shino M, Takahashi K, Murata T, Iida H, Yasuoka Y, Furuya N. Angiotensin II receptor blockerinduced angioedema in the oral floor and epiglottis. Am J Otolaryngol, 2011. 32(6): 624-6. doi: 10.1016/j.amjoto.2010.11.014.

69. Li CC, Malik SM, Blaeser BF, Dehni WJ, Kabani SP, Boyle N, et al. Mucosal pigmentation caused by imatinib: report of three cases. Head Neck Pathol, 2012. 6(2): 290-5. doi: 10.1007/s12105-011-0325-4.

70. Fessa C, Lim P, Kossard S, Richards S, Penas PF. Lichen planus-like drug eruptions due to betablockers: a case report and literature review. Am J Clin Dermatol, 2012. 13(6): 417-21. doi: 10.2165/11634590-000000000-00000.

71. Balaji G, Maharani B, Ravichandran V, Parthasarathi T. Linezolid induced black hairy tongue. Indian J Pharmacol, 2014. 46(6): 653-4. doi: 10.4103/0253-7613.144942.

72. Kumaraguru J, Flanagan SE, Greeley SA, Nuboer R, Stoy J, Philipson LH, et al. Tooth discoloration in patients with neonatal diabetes after transfer onto glibenclamide: a previously unreported side effect. Diabetes Care, 2009. 32(8): 1428-30. doi: 10.2337/dc09-0280.

73. Petropoulou T, Lagona E, Syriopoulou V, Michos A. Teeth and tongue discoloration after linezolid treatment in children. Pediatr Infect Dis J, 2013. 32(11): 1284-5. doi: 10.1097/INF.0b013e3182a5c42b.

74. Helenius-Hietala J, Ruokonen H, Gronroos L, Rissanen H, Vehkalahti MM, Suominen L, et al. Oral mucosal health in liver transplant recipients and controls. Liver Transpl, 2014. 20(1): 72-80. doi: 10.1002/lt.23778.

75. Hellwig E, Lussi A. Oral hygiene products, medications and drugs - hidden aetiological factors for dental erosion. Monogr Oral Sci, 2014. 25: 15562. doi: 10.1159/000359942.

76. Hu KF, Chou YH, Wen YH, Hsieh KP, Tsai JH, Yang P, et al. Antipsychotic medications and dental caries in newly diagnosed schizophrenia: A 
nationwide cohort study. Psychiatry Res, 2016. 245:45-50. doi: 10.1016/j.psychres.2016.07.047.

77. Epstein JB, Thariat J, Bensadoun RJ, Barasch A, Murphy BA, Kolnick L, et al. Oral complications of cancer and cancer therapy: from cancer treatment to survivorship. CA Cancer J Clin, 2012. 62(6): 40022. doi: 10.3322/caac. 21157. 